\section{Photosynthetic Daily Light Integral During the Seedling Stage Influences Subsequent Growth and Flowering of Celosia, Impatiens, Salvia, Tagetes, and Viola}

\author{
Lee Ann Pramuk ${ }^{1}$ and Erik S. Runkle ${ }^{2}$ \\ Department of Horticulture, Michigan State University, East Lansing, MI 48824
}

Additional index words. bedding plants, marigold, pansy

\begin{abstract}
The photosynthetic daily light integral (DLI) dramatically increases during the spring when the majority of bedding plants are commercially produced. However, the effects of DLI on seedling growth and development have not been well characterized for most bedding plant species. Our objectives were to quantify the effects of DLI on growth and development of Celosia, Impatiens, Salvia, Tagetes, and Viola during the seedling stage and determine whether there were any residual effects of DLI on subsequent growth and development after transplant. Seedlings were grown in growth chambers for 18 to 26 days at $21^{\circ} \mathrm{C}$ with a DLI ranging from 4.1 to $14.2 \mathrm{~mol} \cdot \mathrm{m}^{-2} \cdot \mathrm{d}^{-1}$. Average seedling shoot dry weight per internode (a measure of quality) increased linearly $64 \%, 47 \%, 64 \%$, and $68 \%$ within this DLI range in Celosia, Impatiens, Tagetes, and Viola, respectively. Seedlings were then transplanted to $10-\mathrm{cm}$ containers and grown in a common environment (average daily temperature of $22^{\circ} \mathrm{C}$ and DLI of $8.5 \mathrm{~mol} \cdot \mathrm{m}^{-2} \cdot \mathrm{d}^{-1}$ ) to determine subsequent effects on plant growth and development. Flowering of Celosia, Impatiens, Salvia, Tagetes, and Viola occurred 10, 12, 11, 4, and 12 days earlier, respectively, when seedlings were previously grown under the highest DLI compared with the lowest. Except for Viola, earlier flowering corresponded with the development of fewer nodes below the first flower. Flower bud number and plant shoot dry weight at first flowering (plant quality parameters) decreased as the seedling DLI increased in all species except for flower number of Tagetes. Therefore, seedlings grown under a greater DLI flowered earlier, but plant quality at first flowering was generally reduced compared with that of seedlings grown under a lower DLI.
\end{abstract}

Annual bedding plants are collectively the largest segment of floriculture crop production in the United States, and in 2003 the reported wholesale value was more than $\$ 1.8$ billion (USDA, 2004). Bedding plants are propagated by seeds or cuttings in trays that have small soil volumes and closely spaced growing cells, which creates a high plant density. Once seedlings or cuttings have an established root system and adequate vegetative development, they are transplanted into a larger container and grown until they are marketed. Plants are often exposed to different environmental conditions during these two distinct growing stages.

In northern latitudes (e.g., the United States, Canada, and Europe), the majority of bedding plants are commercially produced in greenhouses from January through May for sales to consumers in spring and early summer. During this production time, the integrated photosynthetic photon flux (daily light integral, or DLI) changes dramatically, depending on time of year, latitude, and weather patterns. For example, the mean outdoor DLI ranges from 5 to 10 $\mathrm{mol} \cdot \mathrm{m}^{-2} \cdot \mathrm{d}^{-1}$ across the northern United States

Received for publication 15 Oct. 2004. Accepted for publication 27 Dec. 2004. We gratefully acknowledge funding from greenhouse growers providing support for Michigan State University floriculture research. We also thank David Joeright for assistance with experimental setup.

${ }^{1}$ Former graduate student.

${ }^{2}$ Assistant professor of horticulture and extension specialist, to whom reprint requests should be addressed; e-mail runkleer@msu.edu. in December to 55 to $60 \mathrm{~mol} \cdot \mathrm{m}^{-2} \cdot \mathrm{d}^{-1}$ in the southwestern United States in May (Korczynski et al., 2002). The amount of light that plants receive in a greenhouse is reduced by $40 \%$ or more by shading from greenhouse glazing and structures (Hanan, 1998). Therefore, bedding plant crops are commercially grown under an average DLI of $<5 \mathrm{~mol} \cdot \mathrm{m}^{-2} \cdot \mathrm{d}^{-1}$ (e.g., in January in Michigan) to more than $25 \mathrm{~mol} \cdot \mathrm{m}^{-2} \cdot \mathrm{d}^{-1}$ (e.g., in April in Arizona).

For many floriculture crops, plant quality and mass generally increase with DLI. For example, flower size and number of geranium (Pelargonium $\times$ hortorum L.H. Bail.), petunia (Petunia $\times$ hybrida Vilm.-Andr.), vinca(Catharanthus roseus L.), and bellflower (Campanula carpatica Jacq.) increased as DLI increased (Armitage and Wetzstein, 1984; Graper and Healy, 1991; Niu et al., 2001a, 2001b; Pietsch et al., 1995). In addition, flowering time decreased as DLI increased in several species, including geranium, pansy (Viola $\times$ wittrockiana Gams.), stock(Matthiola incana L.), and petunia (Adams et al., 1997; Armitage and Wetzstein, 1984; Carpenter and Rodriquiz, 1971; Dansereau et al., 1998; Erickson et al., 1981; Kacsperski et al., 1991). However, plant temperature has not been measured in many DLI studies, and the acceleration of flowering from a high DLI can often be at least partly attributed to an increase in plant temperature from increased radiation.

Few DLI studies have been published on some of themosteconomically valuable bedding plant genera, including Viola, Impatiens, and Tagetes. We performed experiments to quantify the effects of DLI on growth, development, and quality of five popular bedding plant species during the seedling stage and to determine whether there were any residual effects of DLI on subsequent growth and development after transplant. Air temperatures and long-wave radiation from lamps were adjusted so that plant temperatures were similar among DLI treatments, so that treatment differences could be primarily attributed to changes in DLI and not temperature.

\section{Materials and Methods}

Initial DLI treatments. Seeds of Celosia argentea var. plumosa L. 'Gloria Mix', Impatiens wallerana Hook. 'Accent Red', Salvia splendens Sell ex Roem. \& Schult. 'Vista Red', Tagetes patula L. 'Bonanza Yellow', and Viola 'Crystal Bowl Yellow' were sown into 288-cell trays at a commercial greenhouse (Raker's Acres, Inc. Litchfield, Mich). Five days after sowing, trays were delivered and cut in half, and two half-trays (blocks) of each species were randomly placed in three growth chambers (Conviron E15, Winnipeg, Canada).

A high light (HL) chamber was fitted with six 160-W fluorescent tubes and ten 25-W incandescent bulbs; the medium light (ML) chamber contained eight fluorescent tubes (four painted black) and 10 incandescent bulbs (four painted black); and the low light(LL) chamber contained 10 fluorescent tubes (eight painted black), and six incandescent bulbs (three painted black). Bulbs were painted black so that they emitted long-wave but not photosynthetic radiation. The photometric red (600 to $700 \mathrm{~nm}$ ) to far-red (700 to $800 \mathrm{~nm}$ ) ratio was measured in each chamber with a spectroradiometer (LI-1800; LI-COR, Lincoln, Nebr.) and was 3.56, 3.56, and 3.58 for the HL, ML, and LL chambers, respectively. Each chamber was initially set at about $21^{\circ} \mathrm{C}$, but minor set point adjustments were made so that plant temperature was about $21^{\circ} \mathrm{C}$. A vapor pressure deficit(VPD) of $0.6 \mathrm{kPa}$ was maintained and the photoperiod was $16 \mathrm{~h}$.

In each chamber, air temperature was moni-

Table 1. The actual average daily light integral (DLI), air temperature, plant shoot-tip temperature, and vapor pressure deficit (VPD) measured inside growth chambers with three DLI treatments during two experimental repetitions $(\mathrm{R}) . \mathrm{LL}=$ low light; $\mathrm{ML}=$ moderate light; $\mathrm{HL}=$ high light.

\begin{tabular}{|c|c|c|c|c|c|c|c|c|}
\hline \multirow[b]{2}{*}{$\mathrm{R}$} & \multirow[b]{2}{*}{ Treatment } & \multirow{2}{*}{$\begin{array}{c}\text { Avg } \\
\text { DLI } \\
\left(\mathrm{mol} \cdot \mathrm{m}^{-2} \cdot \mathrm{d}^{-1}\right)\end{array}$} & \multirow{2}{*}{$\begin{array}{l}\text { Avg air } \\
\text { temp } \\
\left({ }^{\circ} \mathrm{C}\right)\end{array}$} & \multicolumn{4}{|c|}{ Avg shoot-tip temp $\left({ }^{\circ} \mathrm{C}\right)$} & \multirow{2}{*}{$\begin{array}{l}\text { Avg } \\
\text { VPD } \\
(\mathrm{kPa})\end{array}$} \\
\hline & & & & Salvia & Impatiens & Celosia & Tagetes & \\
\hline \multirow[t]{2}{*}{1} & LL & 4.5 & 21.0 & 21.1 & 21.7 & 21.5 & 20.5 & 0.6 \\
\hline & ML & 7.2 & 21.4 & 21.6 & 21.9 & 21.6 & 21.2 & 0.6 \\
\hline \multirow[t]{4}{*}{2} & HL & 14.2 & 21.0 & 21.3 & 21.6 & 21.4 & 20.7 & 0.6 \\
\hline & LL & 4.1 & 20.8 & 21.6 & 20.8 & 21.5 & 20.6 & 0.7 \\
\hline & ML & 7.1 & 21.4 & 21.5 & 21.9 & 21.7 & 21.3 & 0.6 \\
\hline & $\mathrm{HL}$ & 12.3 & 21.4 & 21.4 & 21.6 & 21.1 & 20.6 & 0.6 \\
\hline
\end{tabular}


tored by an aspirated thermocouple, and plant shoot-tip temperatures were monitored by type Ethermocouples(TT-E-40; Omega Engineering Inc., Stamford, Conn.) inserted $\leq 0.5 \mathrm{~cm}$ below shoot apices. Light intensity was monitored in each chamber with a line quantum sensor (Apogee Instruments, Inc., Logan, Utah) and a quantum sensor(LI-COR). Adatalogger(CR10; Campbell Scientific, Logan, Utah) recorded the environmental data every $10 \mathrm{~s}$, and hourly averages were recorded. Actual average DLI, air temperature, shoot-tip temperature, and VPD from the start of treatments to the end of the seedling stage were calculated (Table 1). In addition, canopy temperature was monitored on each crop for $24 \mathrm{~h}$ by an infrared sensor (IRt/c.01; Exergen Corp., Watertown, Mass.) placed about $20 \mathrm{~cm}$ above the canopy at a $45^{\circ}$ angle. The difference between average plant canopy temperature and average air temperature was between 0.1 and $1.6^{\circ} \mathrm{C}$ for all species and DLI treatments (data not shown).

Seedlings were subirrigated with well water containing $\left(\mathrm{mg} \cdot \mathrm{L}^{-1}\right): 95,34$, and $29 \mathrm{Ca}, \mathrm{Mg}$, and $\mathrm{S}$, and supplemented with a water-soluble fertilizer to provide the following $\left(\mathrm{mg} \cdot \mathrm{L}^{-1}\right): 40$ $\mathrm{N}, 4 \mathrm{P}, 40 \mathrm{~K}, 5 \mathrm{Ca}, 0.3 \mathrm{Fe}, 0.03 \mathrm{~B}$, and $\mathrm{Mo}$, and 0.2 Mn, $\mathrm{Zn}, \mathrm{Cu}$ (MSU Special; Greencare Fertilizers, Chicago, Ill.). The water was also acidified with $\mathrm{H}_{2} \mathrm{SO}_{4}$ to a titratable alkalinity of $\mathrm{CaCO}_{3}$ at about $140 \mathrm{mg} \cdot \mathrm{L}^{-1}$.

Tagetes, Celosia, Impatiens, Salvia, and Viola were transplanted (the end of the seedling stage) after 18, 19, 22, 22, and $26 \mathrm{~d}$ under the initial DLI treatments, respectively. Plantheight from soil level to shoot apex, node number, shoot (stems and leaves) dry weight (after $\geq 3$ $\mathrm{d}$ at about $60^{\circ} \mathrm{C}$ ), and the presence of visible

Table 2. The effect of daily light integral (DLI) during the seedling stage on node number and stem length of seedlings at transplant and on subsequent flower size at first flowering $(n=16)$.

\begin{tabular}{|c|c|c|c|}
\hline $\begin{array}{l}\text { Avg DLI } \\
\left(\mathrm{mol} \cdot \mathrm{m}^{-2} \cdot \mathrm{d}^{-1}\right)\end{array}$ & $\begin{array}{l}\text { Avg node } \\
\text { no. }\end{array}$ & $\begin{array}{l}\text { Avg stem } \\
\text { length }(\mathrm{cm})\end{array}$ & $\begin{array}{l}\text { Avg flower } \\
\text { size }(\mathrm{cm})\end{array}$ \\
\hline \multicolumn{4}{|l|}{ Celosia } \\
\hline 4.1 & 4.3 & 2.4 & $--^{z}$ \\
\hline 4.5 & 4.6 & 2.7 & --- \\
\hline 7.1 & 4.9 & 2.5 & --- \\
\hline 7.2 & 5.3 & 2.9 & --- \\
\hline 12.3 & 5.0 & 2.6 & --- \\
\hline 14.2 & 5.2 & 2.7 & --- \\
\hline Significance & $* * *$ & $* * *$ & --- \\
\hline $\mathrm{P}_{\text {Linear }}$ & $* * *$ & NS & --- \\
\hline $\mathrm{P}_{\text {Quadratic }}$ & $* *$ & $*$ & --- \\
\hline \multicolumn{4}{|l|}{ Impatiens } \\
\hline 4.1 & 4.0 & 3.0 & 5.0 \\
\hline 4.5 & 4.7 & 3.3 & 4.8 \\
\hline 7.1 & 5.1 & 2.7 & 4.6 \\
\hline 7.2 & 5.5 & 2.9 & 4.6 \\
\hline 12.3 & 4.9 & 2.1 & 4.2 \\
\hline 14.2 & 5.7 & 2.6 & 4.5 \\
\hline Significance & $* * *$ & $* * *$ & $* * *$ \\
\hline $\mathrm{P}_{\text {Linear }}$ & $* * *$ & $* * *$ & $* * *$ \\
\hline $\mathrm{P}_{\text {Quadratic }}^{\text {Linér }}$ & $* *$ & $* * *$ & $* *$ \\
\hline \multicolumn{4}{|l|}{ Salvia } \\
\hline 4.1 & 2.9 & 3.9 & 4.1 \\
\hline 4.5 & 3.0 & 4.1 & 4.0 \\
\hline 7.1 & 3.0 & 3.4 & 4.1 \\
\hline 7.2 & 3.0 & 3.9 & 3.4 \\
\hline 12.3 & 3.0 & 2.3 & 3.8 \\
\hline 14.2 & 3.0 & 2.8 & 3.1 \\
\hline Significance & NS & $* * *$ & $* * *$ \\
\hline $\mathrm{P}_{\text {Linear }}$ & NS & $* * *$ & $* * *$ \\
\hline $\mathrm{P}_{\text {Quadratic }}^{\text {Linear }}$ & NS & NS & NS \\
\hline \multicolumn{4}{|l|}{ Tagetes } \\
\hline 4.1 & 2.8 & 2.8 & 4.0 \\
\hline 4.5 & 3.1 & 3.5 & 4.0 \\
\hline 7.1 & 3.4 & 3.4 & 4.1 \\
\hline 7.2 & 4.0 & 4.0 & 4.4 \\
\hline 12.3 & 3.1 & 3.4 & 4.3 \\
\hline 14.2 & 3.8 & 3.7 & 4.3 \\
\hline Significance & $* * *$ & $* * *$ & $* * *$ \\
\hline $\mathrm{P}_{\text {Linear }}$ & $* * *$ & $* * *$ & $* * *$ \\
\hline $\mathrm{P}_{\text {Quadratic }}$ & NS & $* * *$ & $* *$ \\
\hline \multicolumn{4}{|l|}{ Vola } \\
\hline 4.1 & 3.9 & --- & 3.1 \\
\hline 4.5 & 3.8 & --- & 3.0 \\
\hline 7.1 & 4.6 & --- & 3.0 \\
\hline 7.2 & 5.1 & --- & 3.2 \\
\hline 12.3 & 5.3 & --- & 2.9 \\
\hline 14.2 & 5.6 & --- & 3.1 \\
\hline Significance & $* * *$ & --- & NS \\
\hline $\mathrm{P}_{\text {Linear }}$ & $* * *$ & --- & NS \\
\hline $\mathrm{P}_{\text {Quadratic }}^{\text {Linear }}$ & $* * *$ & --- & NS \\
\hline
\end{tabular}

${ }^{\mathrm{z}}$ Dash indicates data not recorded.

NS,***,**** Nonsignificant or significant at $P \leq 0.05,0.01$, or 0.001 , respectively.

flower bud were recorded for eight seedlings from each block of each species at transplant. Plant height of Viola was not measured because seedlings develop as rosettes.

Common environment. At transplant, 16 seedlings (eight from each block) of each species were potted into $10-\mathrm{cm}$ pots containing a $70 \%$ peatmoss, $21 \%$ perlite, and $9 \%$ vermiculite potting media (SUREMIX, Michigan Grower Products, Inc., Galesburg, Mich.) and randomly placed in a common growth chamber (TC-2; Environmental Growth Chambers, Chagrin Falls, Ohio). Plants were top irrigated with acidified water with a water-soluble fertilizer (as described above) to provide $\left(\mathrm{mg} \cdot \mathrm{L}^{-1}\right): 125$ N, $13 \mathrm{P}, 125 \mathrm{~K}, 110 \mathrm{Ca}, 34 \mathrm{Mg}, 29 \mathrm{~S}, 1 \mathrm{Fe}, 0.1$ $\mathrm{B}$ and $\mathrm{Mo}$, and $0.5 \mathrm{Mn}, \mathrm{Zn}, \mathrm{Cu}$.

The growth chamber was set at $21{ }^{\circ} \mathrm{C}$, and a DLI of $8.5 \mathrm{~mol} \cdot \mathrm{m}^{-2} \cdot \mathrm{d}^{-1}$ was provided by fluorescent and incandescent lamps with a 16-h

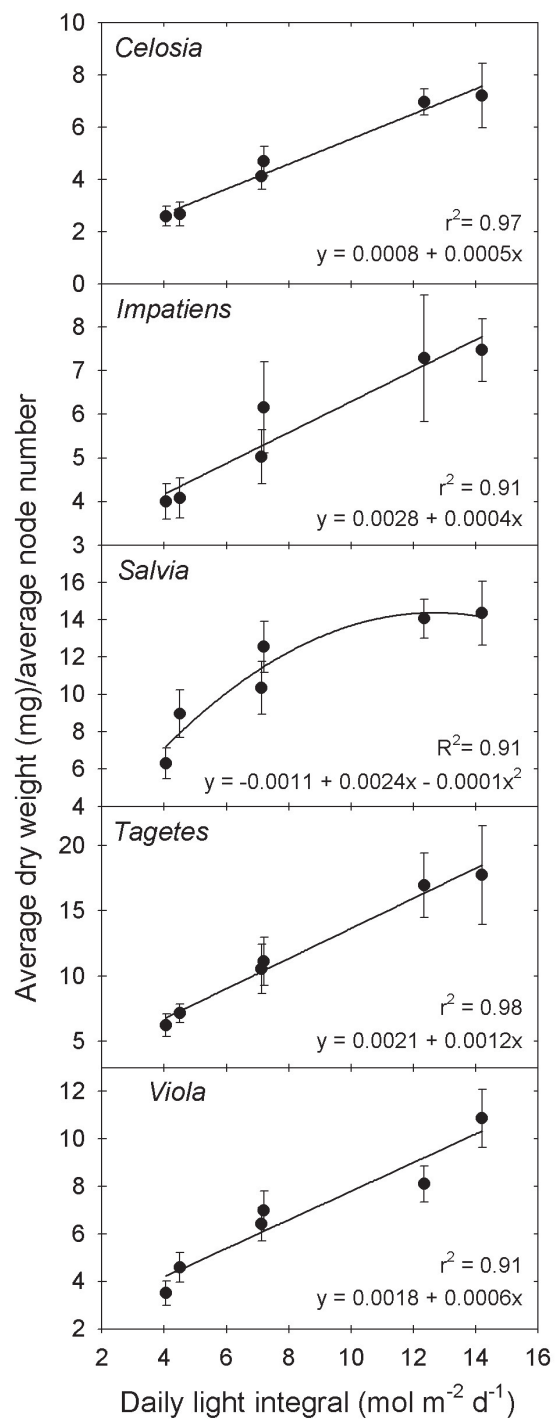

Fig. 1. Relationships between daily light integral and average shoot dry weight per average internode number in Celosia, Impatiens, Salvia, Tagetes, and Viola at seedling transplant. Each symbol represents the average of 16 plants, and error bars represent $95 \%$ confidence intervals. Equations for regression lines are presented with corresponding $r^{2}$ or $R^{2}$ values. 
photoperiod. The VPD was maintained at 0.7 $\mathrm{kPa}$. DLI was monitored with a LI-COR quantum sensor, and air temperature was monitored by an aspirated thermocouple (as described above). Temperature and light values were recorded by a CR 10 datalogger every $10 \mathrm{~s}$, and hourly averages were recorded. The actual air temperature averaged $21.9^{\circ} \mathrm{C}$. When each plant flowered, date of first open flower, plant height, node number below the first flower, flower or inflorescence number, flower size, and shoot dry weight (after $\geq 3 \mathrm{~d}$ at about $60^{\circ} \mathrm{C}$ ) were recorded. Salvia and Celosia were considered in flower when the bottom flower on the spike opened and when the inflorescence reached 4 $\mathrm{cm}$ in length, respectively.

The experiment was performed twice, and data were analyzed using SAS (SAS Institute Inc., Cary, N.C.) general linear model (GLM procedure). Regression procedures were performed in SigmaPlot (SPSS, Chicago, Ill.). Average shoot dry weight per average internode numberwas calculated for each species and used as an indication of seedling quality.

\section{Results}

Seedling stage. Node number increased as DLI increased from 4.1 to $14.2 \mathrm{~mol} \cdot \mathrm{m}^{-2} \cdot \mathrm{d}^{-1}$ in all species except for Salvia (Table 2). In Celosia, Impatiens, Tagetes, and Viola, average shoot dry weight per internode increased linearly $64 \%, 47 \%, 64 \%$, and $68 \%$, respectively, as DLI increased from 4.1 to $14.2 \mathrm{~mol} \cdot \mathrm{m}^{-2} \cdot \mathrm{d}^{-1}$ (Fig. 1). Salvia shoot dry weight per internode increased from 6.4 to $14.4 \mathrm{mg} /$ internode as DLI increased until reaching a maximum at about $12 \mathrm{~mol} \cdot \mathrm{m}^{-2} \cdot \mathrm{d}^{-1}$.

Quadratic or linear relationships relating DLI to seedling stem length (plant height) were observed in all species measured (Table 2). Height of Impatiens and Salvia decreased by $27 \%$ and $37 \%$, respectively, whereas plant height of Tagetes and Celosia increased by $10 \%$ and $12 \%$, respectively, as DLI increased from 4.1 to $14.2 \mathrm{~mol} \cdot \mathrm{m}^{-2} \cdot \mathrm{d}^{-1}$.

Impatiens and Tagetes were the only plants studied to have visible flower buds at transplant, and as DLI increased, the percentage of seedlings at visible bud generally increased (data not shown). Flower buds were visible in $\geq 38 \%$ of Impatiens seedlings under a DLI $\geq 12.3 \mathrm{~mol} \cdot \mathrm{m}^{-}$ ${ }^{2} \cdot \mathrm{d}^{-1}$, whereas seedlings grown under 4.1 or 4.5 $\mathrm{mol} \cdot \mathrm{m}^{-2} \cdot \mathrm{d}^{-1}$ hadnovisibleflowerbuds. All Tagetes seedlings grown under a DLI $\geq 7.2 \mathrm{~mol} \cdot \mathrm{m}^{-2} \cdot \mathrm{d}^{-1}$ were visibly reproductive at transplant, whereas only $56 \%$ of plants had visible flower buds when grown under $4.1 \mathrm{~mol} \cdot \mathrm{m}^{-2} \cdot \mathrm{d}^{-1}$.

\section{Subsequent growth and development}

Celosia. Time to flower decreased by 10 days as DLI during the seedling stage increased from 4.1 to $14.2 \mathrm{~mol} \cdot \mathrm{m}^{-2} \cdot \mathrm{d}^{-1}$ (Fig. 2A). Correspondingly, node number below the first inflorescence decreased by seven as the initial DLI increased from 4.1 to $14.2 \mathrm{~mol} \cdot \mathrm{m}^{-2} \cdot \mathrm{d}^{-1}$ (Fig. 2B). Flower number and shoot dry weight at first flowering decreased linearly (by $61 \%$ and $31 \%$, respectively) as the initial DLI increased within the range studied (Fig. 2C and D). Plant height at flowering also decreased linearly (from 22.2 to $18.7 \mathrm{~cm}$ ) as initial DLI increased from 4.1 to $14.2 \mathrm{~mol} \cdot \mathrm{m}^{-2} \cdot \mathrm{d}^{-1}$ (Fig. 2E).

Impatiens. The relationship between days to flower after transplant and DLI was quadratic; days to flower decreased from 36 to a minimum of $24 \mathrm{~d}$ as the initial DLI increased from 4.1 to about $12 \mathrm{~mol} \cdot \mathrm{m}^{-2} \cdot \mathrm{d}^{-1}$ (Fig. 2F). Additionally, node number below the first open flower decreased linearly from 7 to 4 (Fig. 2G). Flower number and flower diameter decreased linearly from 49 to 20 (Fig. $2 \mathrm{H}$ ) and from 5.0 to 4.5 $\mathrm{cm}$, respectively (Table 2 ). As the initial DLI increased from 4.1 to $14.2 \mathrm{~mol} \cdot \mathrm{m}^{-2} \cdot \mathrm{d}^{-1}$, shoot dry weight and height at first flower decreased linearly by $59 \%$ and $24 \%$, respectively (Fig. $2 \mathrm{I}$ and $2 \mathrm{~J}$ ).

Salvia. Time to flower decreased by 11

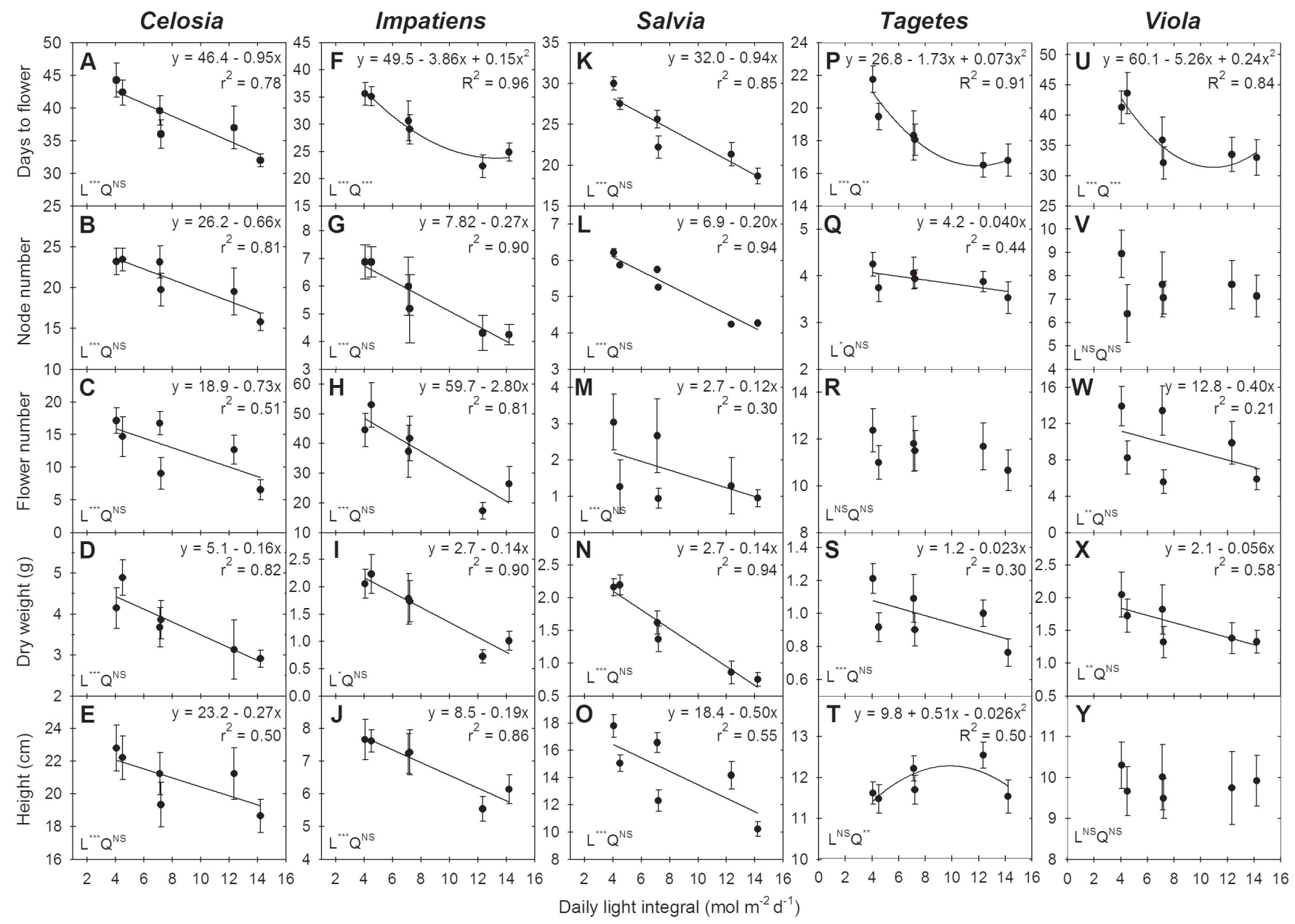

Fig. 2. The effect of daily light integral during the seedling stage on subsequent days to flower, node number, flower number, shoot dry weight, and height in Celosia, Impatiens, Salvia, Tagetes, and Viola. Each symbol represents the average of 16 plants, and error bars represent $95 \%$ confidence intervals. $\mathrm{L}=$ linear and $\mathrm{Q}=$ quadratic. NS,********N Nonsignificant or significant at $P \leq 0.05,0.01$, or 0.001 , respectively. Equations for regression lines are presented with corresponding $r^{2}$ or $R^{2}$ values. 
days as initial DLI increased from 4.1 to 14.2 $\mathrm{mol} \cdot \mathrm{m}^{-2} \cdot \mathrm{d}^{-1}$ (Fig. 2K). Plants developed two fewer nodes below the inflorescence when seedlings were grown under the higher DLIs compared with the lowest DLI (Fig. 2L). Significant linear relationships were also observed between initial DLI and flower number, flower size, shoot dry weight, and height (Fig. 2M, N, and $\mathrm{O}$; Table 2). As initial DLI increased from 4.1 to $14.2 \mathrm{~mol} \cdot \mathrm{m}^{-2} \cdot \mathrm{d}^{-1}$, average inflorescence number decreased from 2 to 1 and flower size decreased from 4.1 to $3.1 \mathrm{~cm}$. Shoot dry weight and height at flowering decreased with increasing DLI by $62 \%$ and $25 \%$, respectively.

Tagetes. Time to flower decreased by only 4 days and average node number decreased slightly (from 4.3 to 3.5 ) as initial DLI increased from 4.1 to about $11 \mathrm{~mol} \cdot \mathrm{m}^{-2} \cdot \mathrm{d}^{-1}$ (Fig. $2 \mathrm{P}$ and $\mathrm{Q})$. Flower number was not influenced by the initial DLI treatments, although flower size decreased slightly (from 4.3 to $4.0 \mathrm{~cm}$ ) as DLI decreased from 14.2 to $4.1 \mathrm{~mol} \cdot \mathrm{m}^{-2} \cdot \mathrm{d}^{-1}$ (Fig. 2R; Table 2). Shoot dry weight at first flowering decreased linearly as DLI during the seedling stage increased (Fig. 2S). Plant height at flowering was quadratically related to the initial DLI (Fig. 2T).

Viola. Time to flower was hastened by 12 days, whereas flower number and shoot dry weight decreased linearly from 11 to 7 and by $26 \%$, respectively, as initial DLI increased from 4.1 to about $11 \mathrm{~mol} \cdot \mathrm{m}^{-2} \cdot \mathrm{d}^{-1}$ (Fig. $2 \mathrm{U}, \mathrm{V}$, and $\mathrm{W}$ ). Node number, flower size, and height at flowering were not significantly influenced by the initial DLI treatments (Fig. 2X and Y, Table 2).

\section{Discussion}

For many commercial growers, a high-quality bedding plant seedling has a large dry mass per internode (i.e., thick stems) and is relatively compact, which facilitates ease of shipping and transplanting. With these parameters for plant quality at transplant, the quality of all species increased as average DLI increased (Fig. 1). Average shoot dry weight per internode continued to increase linearly as initial DLI increased from 4.1 to $14.2 \mathrm{~mol} \cdot \mathrm{m}^{-2} \cdot \mathrm{d}^{-1}$ for all species except $\mathrm{Sal}$ via. The average shoot dry weight per internode of Salvia appeared to reach a maximum when the DLI was about $12 \mathrm{~mol} \cdot \mathrm{m}^{-2} \cdot \mathrm{d}^{-1}$. Additionally, increasing the DLI decreased seedling height at transplant in Celosia, Impatiens, and Salvia, resulting in a more compact seedling.

Subsequent time to flower of all five species decreased as the DLI under which seedlings were grown increased within the DLI range studied. Time to flower of Celosia and Salvia decreased linearly by $24 \%$ and $41 \%$ as DLI increased from 4.1 to $14.2 \mathrm{~mol} \cdot \mathrm{m}^{-2} \cdot \mathrm{d}^{-1}$. Flowering of Tagetes, Viola, and Impatiens was accelerated by $19 \%, 28 \%$, and $33 \%$, respectively, as DLI during the seedling stage increased to about 11 to $13 \mathrm{~mol} \cdot \mathrm{m}^{-2} \cdot \mathrm{d}^{-1}$. Thus, these data indicate that when the ambient DLI is low (e.g., $<8$ $\mathrm{mol} \cdot \mathrm{m}^{-2} \cdot \mathrm{d}^{-1}$ ), supplemental photosynthetic lighting would increase seedling quality and accelerate flowering.

Plants that develop fewer nodes before flower initiation from an increase in DLI have been described as having a facultative irradiance response(Erwin etal., 2004). For example, three Hibiscus spp. flowered earlier and developed fewer nodes below the first flower as DLI increased (Warner and Erwin, 2003). Here, node number below the first open flower decreased in Celosia, Impatiens, Salvia, and Tagetes as the initial DLI increased. Thus, these plants can be described as having a facultative irradiance response.

Erwin et al. (2004) reported that Viola 'Delta Pure White' had a facultative irradiance response, which is not in agreement with this study on Viola 'Crystal Bowl Yellow'. Unpublished research indicates that 'Crystal Bowl Yellow' is less responsive to irradiance than 'Delta Pure White' (J. Erwin, personal communication), which could explain the difference in responses. We exposed Viola seedlings to different DLI treatments for $26 \mathrm{~d}$, while Erwin et al. (2004) grew Viola plants under different DLI treatments from transplant until flowering. These longer DLI treatments on 'Delta Pure White' could have magnified DLI effects on flowering. To our knowledge, similar DLI studies with Impatiens, Salvia, and Tagetes have not been published.

An increase in DLI during the finish stage increased flower number in several garden plant species (Armitage and Wetzstein, 1984; Niu et al., 2001b; Pietsch et al., 1995). An increase in DLI can also increase flower size, as reported in pansy 'Universal Violet' (Adams et al., 1997). This study demonstrates how the DLI during the seedling stage influences subsequent flowering independent of the DLI during the finish stage. Our results indicate that flower number and plant mass (expressed as plant shoot dry weight) at first flowering decreased as the initial DLI increased for all species except flower number of Tagetes (Fig. 2). Seedlings grown under the lower DLI treatments took longer to flower, and thus they had more time to harvest light and develop additional leaves in the subsequent common environment. Therefore, since vegetative phase length increased under low DLI conditions, plants were able to direct more growth to photosynthetic tissues that ultimately resulted in greater flower and plant mass when flowering occurred.

This study quantifies the consequences of growing seedlings under a range of DLIs that are common to commercial greenhouses during late winter and early spring in northern latitudes (e.g., $\left.>40{ }^{\circ} \mathrm{N}\right)$. Early flowering of Celosia, Impatiens, Salvia, and Tagetes in this study can be primarily attributed to the increased DLI during the seedling stage because average plant shoot-tip temperatures were within 0.7 ${ }^{\circ} \mathrm{C}$ among DLI treatments (Table 1) and plants developed fewer nodes before flower initiation with increasing DLI. Although final plant quality (flower number, flower size, and shoot dry weight) was higher when seedlings were initially grown under a low DLI, flowering was delayed compared with that under a higher DLI.

These results indicate that greenhouse growers could manipulate DLI during the seedling stage to accelerate or delay subsequent flowering, but the desired response may depend on the final container size. Earlier flowering of these species could be achieved by providing supplemental lighting to seedlings when the ambient DLI is low (e.g., $\left.<8 \mathrm{~mol} \cdot \mathrm{m}^{-2} \cdot \mathrm{d}^{-1}\right)$. Rapid flowering and lower plant quality (fewer flower buds) at first flowering could be desirable when seedlings are transplanted into small finish containers (i.e., cell packs). In contrast, delayed flowering may be desired when seedlings are transplanted into larger finish containers (i.e., 10-cm pots or hanging baskets). In this scenario, a larger plant could be needed to adequately fill the finish container, and although flowering would be delayed, plants would be of higher quality (greater mass and more flowers) at first flowering.

Future research is warranted to determine how exposure to a high DLI at different stages of seedling development influences plant quality and subsequent flowering. In addition, the interaction of photoperiod and DLI on photoperiodic species needs to be described. Finally, the interaction of DLI with growing temperature has not been described for most bedding plant species.

\section{Literature Cited}

Adams, S.R., S. Pearson, and P. Hadley. 1997. The effects of temperature, photoperiod and light integral on the time to flowering of pansy cv. Universal Violet (Viola $\times$ wittrockiana Gams.). Ann. Bot. 80:107-112.

Armitage, A.M. and H.Y. Wetzstein. 1984. Influence of light intensity on flower initiation and differentiation in hybrid geranium. HortScience 19:114-116.

Carpenter, W.J. and R.C. Rodriguez. 1971. Earlier flowering of geranium 'Carefree Scarlet' by high intensity supplemental light treatment. HortScience 6:206-207.

Dansereau, B., Y. Zhang, and S. Gagnon. 1998. Stock and snapdragon as influenced by greenhouse covering materials and supplemental light. HortScience 33:668-671.

Erickson, V.A.,A.Armitage, W.H.Carlson, and R.M. Miranda. 1981. The effect of cumulative photosynthetically active radiation on the growth and flowering of the seedling geranium, Pelargonium $\times$ hortorum Bailey. HortScience 15:815-817.

Erwin, J., N. Mattson, and R. Warner. 2004. Light effects on annual bedding plants, p. 62-71. In: P. Fisher and E. Runkle (eds.). Lighting up profits: Understanding greenhouse lighting. Meister Media Worldwide, Willoughby, Ohio.

Graper, D.F. and W. Healy. 1991. High pressure sodium irradiation and infrared radiation accelerate Petunia seedling growth. J. Amer. Soc. Hort. Sci. 116:435-438.

Hanan, J. 1998. Greenhouses: Advanced technology for protected horticulture. CRC Press, Boca Raton, Fla

Kaczperski, M.P., W.H. Carlson, and M.G. Karlsson. 1991. Growth and development of Petunia $\times$ hybrida as a function of temperature and irradiance. J. Amer. Soc. Hort. Sci. 116:232-237.

Korczynski, P.M., J. Logan, and J.E. Faust. 2002. Mapping monthly distribution of daily light integrals across the contiguous United States. HortTechnology 12(1):12-16.

Niu, G., R.D. Heins, A.C. Cameron, and W.H. Carlson. 2001a. Day and night temperatures, daily light integral, and $\mathrm{CO}_{2}$ enrichment affect growth and flower development of Campanula carpatica 'Blue Clips'. Scientia Hort. 87:93-105.

Niu, G., R.D.Heins,A.C.Cameron, and W.H.Carlson. 2001b. Temperature and daily light integral influence plant quality and flower development of Campanula carpatica 'Blue Clips', 'Deep Blue Clips', and Campanula 'Birch Hybrid'. HortScience 36(4):664-668.

Pietsch, G.M., W.H.Carlson, R.D. Heins, and J.E. Faust. 1995. The effect of day and night temperature and irradiance on development of Catharanthus roseus (L.) 'Grape Cooler'. J. Amer. Soc. Hort. Sci. 120(5):877-881.

United States Department of Agriculture (USDA), National Agricultural Statistics Service. 2004. Floriculture crops 2003 summary. 15 July 2004. http://usda.mannlib. cornell.edu.

Warner, R.M. and J.E. Erwin. 2003. Effect of photoperiod and daily light integral on flowering of five Hibiscus sp. Scientia Hort. 97:341-351. 